\title{
4 THE WEARING OF HIJAB IN PUBLIC EDUCATIONAL INSTITUTIONS IN NIGERIA: A CALL FOR ALTERNATIVE DISPUTE RESOLUTION
}

\section{Tolulope Anthony Adekola ${ }^{1}$}

\author{
Blessed are the peacemakers, for they will be called children of God. \\ - Holy Bible, Matthew 5:9 \\ If two parties among the believers fall into a quarrel, \\ make ye peace between them. \\ - Quran, Al-Hujurat, 49:9
}

\section{INTRODUCTION}

The word hijab ${ }^{2}$ in the Quran refers to a partition or curtain in the literal or metaphorical sense. ${ }^{3}$ In Islamic parlance, the term has been generally said to mean any head, face, or body covering worn by Muslim women that conforms to a certain standard of modesty. In some quarters, however, the term has also been linked to the separation of a man from a woman. ${ }^{4}$ Hijab is worn by Muslim women as a symbol of modesty and privacy encompassing women's "gaze, gait, garments, and genitalia". ${ }^{5}$ Some Islamic scholars interpret this type of modest clothing to be the covering of every part of the body except the face, hands up to wrists, and feet. ${ }^{6}$ Other scholars argue that the Quran itself does not mandate that women wear hijab. ${ }^{7}$ They posit that hijab refers to the curtain separating visitors to the Prophet Mohammed's house from his wives' lodgings, and as such the hijab should not be made mandatory for Muslim women, but only for the wives of Mohammed. ${ }^{8}$

1 PhD candidate, School of Law, City University of Hong Kong.

2 Literally, hijab means "woman's veil", "cover", "wrap", “drape, "partition”, or "curtain": Cowan JM (ed). 1980. A Dictionary of Modern Written Arabic. Reprint Edition. Beirut: Libraire du Liban.

3 El Guindi F and Sherifa Z. 2009. "Hijab". The Oxford Encyclopedia of the Islamic World. Revised and Edited Edition. Oxford: Oxford University Press.

4 Glasse C. 2001. The New Encyclopedia of Islam. Revised Edition. Lanham, MD: Altamira Press, 179-180.

5 Martins RC. 2003. Encyclopedia of Islam and the Muslim World. New York: MacMillan, 721.

6 Fisher MP. 2008. Living Religions. New Jersey: Pearson Education.

7 Fisher, Living Religions.

8 See Quran 33:53: "And when ye ask [the Prophet's wives] for anything ye want, ask them from before a screen [hijab]: that makes for greater purity for your hearts and for theirs." See also Ahmed L. 1992. Women and Gender in Islam: Historical Roots of a Modern Debate. New Haven, CT: Yale University Press. 
In light of these arguments touching on conceptualising "hijab", there appears to be a general consensus in Islam that Muslim women and men must dress modestly and not expose their bodies unduly. ${ }^{9}$

The need for women not to expose their body remains a cardinal requirement for women in Islam, however, wearing hijab in secular settings has generated controversies globally. While some nations, particularly in the Middle East, make it mandatory for women to wear hijab, some other countries, particularly in Europe, have passed laws banning some or all types of hijab in public or in certain secular settings. ${ }^{10}$ Despite the absence of any Quranic verse referring to covering hair by men or women, all four schools of both Sunni and Shia Islam officially require women to cover their hair. Under different interpretations of the hadith by Islamic scholars, a majority of the scholars would permit the exposure of the face and feet, while other scholars are of the view that these should be also covered. ${ }^{11}$ The practical result is that some Muslim women, apart from adopting the long loose outer garment (jilbab) and headscarves (khimar) that cover the head, neck and upper body, also adopt the face veil (niqab). Others go further, covering their hands with gloves and their feet with stockings. In this way, no part of the body is exposed to the gaze of strangers. Some, however, leave the hands, feet and face exposed.

Nigeria, the most populous African country, with a population of over 182 million in 2015, is nearly equally divided between Christianity and Islam, though the exact ratio is uncertain. ${ }^{12}$ The majority of Nigerian Muslims are Sunni and are concentrated in the northern region of the country, while Christians dominate in the south. Over the years, students of public institutions in the south have had to adhere strictly to the prescribed school uniforms by the state governments. The prescribed school uniform often prohibits the use of hijab or other head coverings. In recent times, Muslim students in the southern part of Nigeria are increasingly accepting the traditional teachings of Islam on dressing. The most visible expression of this "revivalism" is perhaps the adoption of the hijab by many female Muslim students.

9 There are other specific Quranic references to types of women's clothing that are used to justify covering hair. See Quran 24:31, 33:59 and 24:30-31.

10 Laborde C. 2012. "State Paternalism and Religious Dress", International Journal of Constitutional Law 10:398.

11 The majority relies essentially on the following, which was reported from the Prophet (SAW): "Asma, daughter of Abu Bakr, entered upon the Apostle of Allah (peace be upon him) wearing thin clothes. The Apostle of Allah (peace be upon him) turned his attention from her. He said: “O Asma', when a woman reaches the age of menstruation, it does not suit her that she displays her parts of the body except this and this, and he pointed to her face and hands." Abu Dawood S. n.d. Dar Ihyau al-Sunnah Al-Tabauyat, hadith no. 4092. See the detailed consideration of this view in Al-Muhajabah, "Opinion of scholars in favor of displaying the face and hands". Online at: http://www.muhajabah.com/scholars.htm. Also see, generally, Mutahhari M. 1987. On the Islamic Hijab. Tehran: Islamic Propagation Organisation.

12 United Nations, Department of Economic and Social Affairs, Population Division. 2015. World Population Prospectus: The 2015 Revision, 21. 
Nevertheless, in some institutions, the authorities have attempted to subvert the hijab by introducing dress codes for their students. While some institutions prohibit only the niqab, others prohibit other versions of the hijab, even the khimar. ${ }^{13}$

The dress codes and the hijab prohibition have caused a monumental divide along political and religious lines in Nigerian educational institutions and the wider society. While the affected students argue that the dress codes violate their constitutionally guaranteed fundamental right to practise and observe the tenets of their religion, secular school authorities and state governments argue that the preservation of secularism and neutrality in public spaces will guarantee religion peace and tolerance for the nation. Adherents of other religions have also joined in the argument as interested stakeholders by arguing against the use of hijab and sometimes seeking the right to to display their religious emblems in public schools.

This chapter is an analysis of court cases governing dress codes and hijab regulation in Nigeria. In the light of the benefits it might offer in these cases, the recommendation is for methods of alternative dispute resolution (ADR), rather than litigation in religious dispute settlements in these cases. The chapter reviews three cases that arose in Nigerian educational institutions between the years 2007 and 2017. Two of the cases are in the southern part of Nigeria, while the other, which was not a subject of litigation, relates to the Nigerian Law School. What these cases have in common is that the plaintiffs, who were students of public institutions, approached the court for the enforcement of their fundamental right to express their faith by wearing hijab.

\section{CONSTITUTIONAL GUARANTEE OF RIGHT TO FREEDOM OF RELIGION}

The Constitution of the Federal Republic of Nigeria, 1999, provides in Section 10 that: "The Government of the Federation or of a state shall not adopt any religion as State Religion."14 By this provision, religion is separated from the state in Nigeria. The Section 10 provision is necessary due to the peculiar nature of the Nigerian state being a pluralistic nation with diverse religious and ethnic groups. ${ }^{15}$ To ensure that every person in Nigeria holds and practises a religion of their choice, the Section 10 of the Nigerian Constitution further provides:

(1) Every person shall be entitled to freedom of thought, conscience, and religion, including freedom to change his religion or belief, and the freedom (either alone or in community with others and in public or private) to manifest and propagate his religion or belief in worship, teaching, practice and observance. from Nigeria and Beyond". Identity, Culture and Politics: An Afro-Asian Dialogue 10(1):51-74. 
(2) No person attending any place of education shall be required to receive religious instruction or take part in or attend any religious ceremony or observance if such instruction, ceremony or observance relates to a religion other than his own or a religion not approved by his parent or guardian.

(3) No religious community or denomination shall be prevented from providing religious instructions for pupils of that community or denomination in any place of education maintained wholly by that community or denomination.

(4) Nothing in this Section shall entitle any person to form, take part in the activity or be a member of a secret society.

Section 38 is in line with the international law provisions of the Universal Declaration of Human Rights which guarantee freedom of thought, conscience and religion and the freedom to change religious belief. ${ }^{16}$

Nevertheless, as good as the right to freedom of religion is, there seems to be tension when one considers the right to propagate and manifest one's religion. ${ }^{17}$ Although it has been argued that the exercise of freedom to believe in a religion does not pose any challenge per se, inasmuch as belief resides in the mind of the believer, the area of conflict emerges when followers of particular religious beliefs engage in the exercise of their rights to engage in propagating their religious beliefs in a manner considered to be offensive, insensitive or provocative to persons of other religions. ${ }^{18}$ Some of the tensions occasioned by the interface between the freedom of religion, the right to manifest religious belief and the protection of the overriding public interest are considered in the cases under review in this chapter.

\section{Bashirat Saliu \& 2 Others $v$ The Provost Kwara State College of Education, Ilorin}

The facts of the case, as contained in the judgment, were that three applicants were female Muslim students of Kwara State College of Education, Ilorin, whose lives were guided by Islamic doctrines approached the High Court to challenge a circular titled "Dress Code for students of the College" issued by the management of the College of Education. ${ }^{19}$ Article J of the dress code prohibited the wearing of "dresses/ apparels that cover the entire face of any student in order to aid face identity and enhance security on campus. ${ }^{20}$ Acting pursuant to this article, the college prevented

16 Universal Declaration of Human Rights, art 18.

17 Kawu SD. 2016. "Religious rights in a pluralistic world: The Nigerian experience". Presentation at a symposium held at Brigham Young University Provo, Utah, 1-4 October. The author is Chief Judge of Kwara State, Nigeria.

18 See the general review of some of these documents in Dhokalia RP. 1986. "The Human Right to Religious Freedom: Problems of Effective Enjoyment", Calabar Law Journal 1(1):97-98.

19 See Bashirat Saliu \& 2 Others $v$ The Provost Kwara State College of Education, Ilorin Court of Appeal No CA/IL/49/2006.

20 Bashirat Saliu \& 2 Others $v$ The Provost Kwara State College of Education. 
the students from attending lectures and writing examinations. The students therefore approached the High Court, which is the court of first instance in Nigeria. The arguments in the case were quite interesting. The students contended that since the veil is part of their religion, it falls within the ambit of their fundamental right to religion as enshrined in Section 38(1) of the Constitution. Judgment was entered in favour of the students, but the college, dissatisfied with the judgment, appealed to the Appellate Court. ${ }^{21}$ An examination of this case is significant in this chapter, because it is the first case that revolves around the use of hijab in public educational institutions in Nigeria.

At the Appellate Court, the main controversy in the students' case was whether the right to wear the veil at the college was a right under Section 38 of the Nigerian Constitution. The students' counsel contended that since the veil is part of the Islamic religion, it fell within the ambit of their fundamental right to religion as enshrined in the Constitution. ${ }^{22}$ Counsel further relied on the provisions of the Quran and submitted that the wearing of the veil by the respondent is an Islamic injunction, ${ }^{23}$ which the respondents had chosen to obey irrespective of whether it is compulsory. The students' counsel also countered the submission of the college that students might hide under the veil to commit crimes, such as cultism, ${ }^{24}$ indiscipline or cheating during examinations, as speculative and baseless.

The counsel to the College of Education, for his part argued that the college had not restrained or disturbed the students from praying, preaching, teaching or propagating their religion on or off campus. He argued, further, that wearing of apparel that totally covers the face is not compulsory in Islam and, as such, cannot translate into a fundamental right to freedom of thought, conscience and religion. ${ }^{25}$ The lawyer for the college also submitted that the College of Education is a secular educational institution where students are treated without discrimination and that faces and eyes of students must be seen for effective communication and identification. ${ }^{26}$

In resolving these arguments, the Appellate Court held that the respondents had a constitutional right to freedom of thought, conscience, and religion and that the veil of the respondent qualified as a fundamental right under Section 38(1) of the Nigerian Constitution. It was further resolved that it was immaterial whether the wearing of the veil is compulsory in Islam. The emphasis was, therefore, to be on the students' right to manifest and propagate their religion or belief in worship, teaching, practice and observance.

21 Bashirat Saliu \& 2 Others $v$ The Provost Kwara State College of Education.

22 Constitution of the Federal Republic of Nigeria, sec 38(1).

23 Quran, 17:45, 24:3, 33:59.

24 Cultism, in this context, means a sect with a religious philosophical identity sometimes viewed as anti-social, often existing on the margins of society or exploitative towards its members.

25 Constitution of the Federal Republic of Nigeria, sec 38.

26

Bashirat Saliu \& 2 Others $v$ The Provost Kwara State College of Education. 
Another issue that was argued in the case was whether the dress code specifications in the controversial Article J could be accommodated under the exceptions in Section 45 of the Nigerian Constitution. It is important to note that Section 45 specifies instances where a fundamental right of a citizen can be mortgaged in "the interest of defense, public safety, public order, public morality or public health and the protection of rights of other persons". The court held that the dress code, being a mere administrative rule and not a legislative enactment, could not fall under the exceptions in Section 45 of the Constitution. ${ }^{27}$ The court held, further, that the college had failed to prove that the dress code was imposed in service of an overriding interest of the public or the protection of the rights of other persons.

Another issue raised by the college was whether the applicants had waived their rights to freedom of religion by signing the college's matriculation oath ${ }^{28}$ upon their admission. Counsel to the applicants argued based on the principle of volenti non fit injuria, which means that when a party consents to an injury, they can no longer complain, and that the students, having sworn to abide by the rules and regulations of the college, had mortgaged their rights to complain. The court held that signing the matriculation oath could not constitute a waiver of a fundamental human right. According to the court, the right to freedom of religion is inalienable and conferred on every human by the virtue of being human and as such cannot be surrendered. ${ }^{29}$ Thus the court held that the right of Muslim women to wear hijab on the school campus and anywhere else is protected under the Nigerian Constitution. The court also emphatically noted that the hijab, being part and parcel of Islamic mode of dressing and by whatever standard a dignified or vividly decent one, cannot be taken away by any other law other than the Constitution. ${ }^{30}$

As fierce as the legal battle in this case was, the wider tension it triggered in Kwara State and the nation as a whole became more of a religious tussle than a court case involving the enforcement of fundamental rights. While a section of the society believed that the management of the College of Education targeted the Article J dress code at Muslim students, another segment, particularly Christians, believed that the judges of the High Court and Appellate Court who decided the cases in favour of the female Muslims students did so because they were Muslims and therefore must have been influenced by their religious convictions. This facilitation of wider tensions is one of the disadvantages of litigation in settling religious disputes.

See general judgment in Bashirat Saliu \& 2 Others $v$ The Provost Kwara State College of Education.

A matriculation oath is taken by students upon admission stating amongst other things that they will strictly abide by the rules and regulations of the institution.

Bashirat Saliu \& 2 Others $v$ The Provost Kwara State College of Education.

Bashirat Saliu \& 2 Others $v$ The Provost Kwara State College of Education. 


\section{Sheik Salaudeen Ade Olayiwola \& 3 Others v The Government of Osun State 31}

In this case, the applicants, who were female secondary school students in Osun State, South Western Nigeria applied to the High Court for the enforcement of their rights as guaranteed under Sections 38 and 42 of the Nigerian Constitution. ${ }^{32}$ The rights that the students sought to enforce revolved around their right to wear hijab. The originating summons was supported with a 44-paragraph affidavit, statement, written address of counsel and a number of exhibits, including a copy of a document, published by the Ministry of Education, Osogbo Osun State, Nigeria in 2004, titled "Guidelines on Administration and Discipline in Osun State Public Schools", which was the subject of dispute in the case. ${ }^{33}$ The applicants stated the essence of their grievances as based on the following grounds:

(1) The use of Hijab or head cover is compulsory in Islam on every Muslim Female Students.

(2) By virtue of Section 38 of 1999 Constitution of the Federal Republic of Nigeria, everybody is entitled to the right to freedom of religion, conscience, and thought.

(3) The Government of Osun State issued what it calls "Guidelines on Administration and Discipline in Public Schools in Osun State. Article 8.2(v) of which forbids the use of Hijab in some Public Schools.

(4) Pursuant to the said "Guidelines on Administration and Discipline in Public Schools in Osun State", the Government of Osun State deny the Muslim female students the use of Hijab in the Public Schools in Osun State and the Muslim female students who use Hijab in some Public Schools are beaten, embarrassed and tortured by the agents of the Respondents. ${ }^{34}$

It is important to note that, after this case was filed in the Osun State High Court, the Christian Association of Nigeria Osun State Branch applied to join as an interested party in the matter, and the application was granted. The court also invited the Christian Lawyers Association of Nigeria and the Muslim Lawyers Association of Nigeria to become parties in the case as amici curiae, or "friends of the court". ${ }^{35}$

The first issue for determination was whether the wearing of hijab is part of the fundamental right of the Muslim female students in public schools in Osun State under the freedom of religion provisions in Section 38 of the Nigerian Constitution.

31 Sheik Salaudeen Ade Olayiwola \&3 Others v The Government of Osun State Suit no. Hos/M.17/2013. Online at: https://media.premiumtimesng.com/wp-content/files/2016/06/Osun-HijabJudgement.pdf

32 The application was brought pursuant to Order 1 Rule 2 of the Fundamental Rights (Enforcement Procedures) Rules 2009, as preserved by Constitution of Federal Republic of Nigeria, sec 315.

33 Sheik Salaudeen Ade Olayiwola \& 3 Others $v$ The Government of Osun State.

34 Sheik Salaudeen Ade Olayiwola \& 3 Others $v$ The Government of Osun State.

35 Sheik Salaudeen Ade Olayiwola \& 3 Others $v$ The Government of Osun State. 
The students' counsel argued that the wearing of hijab is a fundamental right of the female students in public schools, but that these rights were being curtailed illegally by the respondent. Counsel also drew the attention of the court to the decision of the Court of Appeal, Ilorin Division, in the Bashirat Saliu case, ${ }^{36}$ and its holding that the wearing of hijab by Muslim female students is part of the fundamental right of freedom of religion of Muslim students.

The opposing counsel argued that Section 38(I) of the Nigerian Constitution, upon which the applicants relied, was not helpful to their cause. He argued that the guidelines on the dress code of students in public secondary schools in Osun State were made in the overriding public interest and that even the Constitution did not confer an absolute right of freedom of religion on citizens of Nigeria. ${ }^{37}$ The opposing counsel noted further that Bashirat Saliu ${ }^{38}$ was distinguishable from the instant case because the Osun State public schools have a prescribed uniform, while the Kwara State College of Education in the latter case had no prescribed uniform except for the dress code.

The Christian lawyers, who were invited by the court as amici curiae, ${ }^{39}$ advised the court to transfer the case to a mediation centre in the light of the religious tension in the country. It was further submitted that adherents of other religions might be encouraged to put on their particular religious garments, in actions which might cause chaos in the society. The court declared that Article 8.2(v) of the "Guidelines on Administration and Discipline", prohibiting the use of hijab in all public secondary schools and excluding government-owned Islamic schools, was not only discriminatory against Muslim female students, but also was inconsistent with Section 38 of the Nigerian Constitution and a clear violation of the fundamental right of Muslim female students in public schools in Osun State to freedom of religion. The argument, therefore, was that the disciplinary guideline regarding hijab was null, void and of no effect whatsoever.

The court also declared that acts of molestation, harassment, torture, embarrassment and humiliation to which Muslim female students in public primary and secondary Schools in Osun State were subjected constitute a clear infringement on the fundamental right of the said Muslim female students to religion, conscience and thought, as well as their fundamental right to dignity of human person and right against torture, inhuman and degrading treatment. ${ }^{40}$ Consequently, the court gave an order to restrain the respondents and their servants, agents and privies from disallowing the wearing by Muslim female students in public primary and

36 Bashirat Saliu \& 2 Others $v$ The Provost Kwara State College of Education.

37 Bashirat Saliu \& 2 Others $v$ The Provost Kwara State College of Education.

38 See general judgment in Bashirat Saliu \& 2 Others $v$ The Provost Kwara State College of Education.

39 An amicus curiae (literally, "friend of the court"; plural, amici curiae) is someone who is not a party to a case and may or may not have been solicited by a party and who assists a court by offering information, expertise, or insight that has a bearing on the issues in the case.

40 See the judgment in Sheik Salaudeen Ade Olayiwola $\mathcal{E} 3$ Others $v$ The Government of Osun State. 
secondary schools in Osun State of Islamically prescribed hijab in the premises of the schools, both during and after school hours.

The outcome of this case did not go well with the losing parties, particularly the Christian Association of Nigeria. After the judgment, the Osun State chapter of the Christian Association of Nigeria, CAN, warned that Christian students in public schools would start wearing church garments to school, if the government implemented the judgment by the state High Court legalising the wearing of hijab by Muslim students. ${ }^{41}$ The lingering concerns around this issue reflect further shortcomings of litigation in resolving religious disputes of this nature.

\section{The Nigerian Law School case}

The Nigerian government established the Nigerian Law School in 1962 with the sole objective of providing practical training for both local and foreign-trained lawyers. ${ }^{42}$ Prior to the establishment of the school, practising lawyers in Nigeria had been trained and called to the English bar in England. ${ }^{43}$ In the law school, students were expected to attend the dinners wearing the "regulation dress". For the males, this was interpreted to mean a white shirt, black tie and dark suit. For the females, the regulation dress was derived from England and described thus:

Women barristers should wear ordinary gowns and wig which should completely cover and conceal the hair and hands. Dress should be plain black or very dark, high to the neck with long sleeves and not higher than the gown, with a high plain white collar. Alternatively, plain coats and skirts may be worn black or very dark, not higher than the gown, with plain shirts and high collars. ${ }^{44}$

The Council of Legal Education in Nigeria and the Nigerian Law School interpreted the conventional dress for women thus: "For female students, white blouse, dark jacket and black skirts covering the knees (dark suit) or dark ladies dress and black shoes are to be worn. There should be no embroidery and trimmings of any type and only moderate jewelry (earrings, and watches) are allowed to be worn." 45 Thus, regulation dress for women was either a black dress or black dress suit over white blouses.

41 See Oluwole J. 2016. “Nigeria: Osun Hijab Crisis - CAN Warns of 'Christian Garments' in Public Schools", Premium Times, 10 June.

42 Nigerian Law School Lagos. "About Us". Online at: www.lawschoollagos.org/about/ [Accessed 21 November 2009].

43 Mitee LE. 2008. "Introduction to Nigerian Legal Education", Nigerian Law Resources, 29 March.

44 Circular issued by the Council of Legal Education to the students of the Nigeria Law School (quoted in Fayokun K. 2003. "Limits to the Campus Dress Codes", Journal of International and Comparative Law 7(1):25). See also Orojo JO. 1979. Conduct and Etiquette for Legal Practitioners. London: Sweet and Maxwell, 76.

45 See Council of Legal Education, Nigeria Law School, Lagos Campus. "Code of Conduct for Law Students". Online at: http://www.lawschoollagos.org/wp-content/uploads/2017/11/ code-of-conduct-for-law-students-lagos-campus.pdf [Accessed 8 April 2019]. 
In both cases, women were to leave their head bare, without any headcovering, in the manner of English women, as a matter of practice, even though there is nothing in the rules that requires this. The prohibition of head covering became controversial when female students in khimar started gaining admission to Nigerian Law School. It has remained a continuing controversy. On some campuses of the law school, women are permitted to wear a black skull cap, which they purchase at exorbitant prices. In other campuses, the caps are not allowed. In any case, the cap does not meet the minimum Islamic requirement for head covering, since the caps leave part of the hair, the ears and the neck bare.

Although there is a strong opposition to the law school's policy on the hijab, ${ }^{46}$ the Nigerian Law School has not been challenged in court. This may be due to the fear of aggrieved students as to the possible consequences to their careers. The Nigerian Law School, together with its controlling body, the Council of Legal Education, enjoys a monopoly on legal education in the country and an unfettered discretion on whom to admit to the Nigerian Bar. The fear may be that once a student incurs the wrath of the authorities of the school and the council, he or she can forget about becoming a lawyer in the country.

In fact, at the Nigerian Law School 2017 Call to Bar Ceremony, a Muslim woman graduate, Amasa Firdaus, ${ }^{47}$ was denied the prestigious honour of being called to the Nigerian bar for refusing to remove her hijab at the venue of the ceremony. Back and forth arguments were bandied for and against Firdaus's refusal to conform to the dictates of the law school. But the case also be seen as a venue for alternative dispute resolution, since as the result of a mediatory settlement between the Nigerian Law School and Amasa Firdaus, Firdaus as eventually called to bar on 10 July 2018. ${ }^{48}$ Although Firdaus did not approach the court to seek redress against the Nigerian Law School, the action of stakeholders in the crisis to reach an amicable settlement out the battle of the courtroom is commendable. If litigation had been used in settling this dispute, three things would have happened: (1) the religious tension in the country would have escalated and this would have led to bitterness and hatred along religious lines, (2) the delay in the judicial system would have extended the lifespan of the crisis in a way that would not have been healthy for the nation, as the delay would have further aggravated the already tense atmosphere, and (3) finally, but most practically, Firdaus would not have

46 Bayero M. 1998. “The Prescribed Mode of Female Dressing by Allah's Shari'ah: A Case for Muslim Lawyers", Al-Maslaha - A Journal of Law and Religion (1):192-209; Oba AA. 2004. "Lawyers, Legal Education and Shari'ah Courts in Nigeria", Journal Legal Pluralism 49:113; Oba, "The Hijab in Educational Institutions and Human Rights"; Abdulraheem NM. 2006. "The Hijab, Barristers' Dress Code and Religious Freedom in the Legal Profession in Nigeria", IIUM Law Journal 14(2):253; Badamasiuy JB. 2006. "Dressing and Women in the Legal Profession: Legal and Islamic Perspectives", Al-Maslaha - Journal of Law and Religion 3: 150-154.

47 See "Nigerian law graduate denied call to bar over hijab", Al Jazeera, 16 December 2017, 1.

"Nigerian Law School Calls Miss Amasa Firdaus to Bar", Channels Television, 10 July. 
been called to the Nigerian Bar, if the case had not been settled. The Firdaus case is further justification for consideration of $\mathrm{ADR}$ as a mediating tool in such cases.

\section{ALTERNATIVE DISPUTE RESOLUTION IN THE CONTEXT OF THE NIGERIAN HIJAB CASES}

Although the Nigerian Legal system does not expressly bar litigants from approaching the court to seek redress when there are conflicts, the courts in Nigeria have in recent times advised litigates to explore the use of Alternative Dispute Resolution. The practice in Nigeria is that if parties can reach an amicable settlement, their amicable resolution can be adopted as a consent judgment. Mediation is a voluntary process in which a neutral third party (the mediator) helps the disputing parties communicate with each other and reach a mutually acceptable agreement. ${ }^{49}$ Typically, mediation is characterised by being voluntary and informal, as well as private and confidential, and is aimed at reducing hostility and preserving ongoing relationships. The mediator, reconciliator or arbitrator does not render a decision nor does he or she forces the parties to reach an agreement. As in a negotiation, the parties directly participate in the mediation and are responsible for reaching their own, mutually acceptable settlement or agreement. Indeed, it can be argued that many of the principles of ADR are deeply rooted in Christianity and Islam, as well as in African traditional religions, which are Nigeria's three main religious groups, though with Christianity and Islam generally being the main contenders over hijab and religious symbols thus far.

Christians draw their traditions of faith-based dispute resolution from the Bible, particularly the teachings of Jesus Christ. Basically, Jesus taught that all people had to work out their differences in order to receive salvation, saying, "Love your enemies, do good to those who hate you, bless those who curse you, pray for those who ill treat you. If someone strikes you on one cheek, turn to him also the other. Both mediation and conciliation are also the preferred dispute resolution approaches of the Prophet Mohammed. The validity of ADR in Islam can be derived from the verse, or ayat, of the Quran, which says: "The believers are but a single brotherhood, so make peace and reconciliation (sulh) between two (contending) brothers; and fear Allah, that ye may receive mercy." 50 As noted above in the epigram to this chapter, another ayat of the Quran says: "If two parties among the believers fall into a quarrel, make ye peace between them ... with justice, and be fair; for Allah loves those who are fair and just." ${ }^{11}$ The provisions above, taken from the holy books of both the Christian and Muslim traditions, strengthen the argument for ADR as an alternative to litigation in the settlement of religious disputes.

49 For an example from the United States, see Oklahoma Bar Association. 2015. "Methods for Resolving Conflicts and Disputes", August. Online at: https://www.okbar.org/ freelegalinfo/disputes/

Quran, Surah Al-Hujarat, 49:10.

51

Quran, Surah Al-Hujurat, 49:9. 
Conflicts are inevitable in any human society, be it at the family, national or international level. The conflict may occur between people of the same or different ethnic, religious or cultural backgrounds. The nature and extent of the conflicts largely depend on the level of tolerance of the people. Sometimes the attitude of government and security apparatus, charged with the responsibility of maintaining law and order and the performance of the justice sector with respect to breaches or threatened breach of peace, instead leads to injustice. In Osun State, following a court order that upheld the right of Muslim girls to wear the headscarf, ${ }^{52}$ Muslim female pupils came to school with their hijab, and their Christian counterparts turned up dressed in choir and other religious costumes. ${ }^{53}$

It is possible that one may think that the hijab controversy is merely an issue revolving around the Islamic veil, but taking a deeper look, it is much more than that. The hijab crisis has taken on the colour of a religious crisis in Nigeria, as is suggested in these various instances of litigation. The South West region of Nigeria, in particular, has recorded a track record of peaceful coexistence amongst Christians, Muslims, and adherents of other religions and belief systems, compared to their counterparts in the North, where the relationship between the adherents of the various religions is often characterised by violence and bloodshed.$^{54}$ However, the cloud of tension is thick, and increases in the number of religion cases in court aggravates the already tense atmosphere. For instance, In Lagos state south west Nigeria, there is still a pending hijab case between Lagos State Government, Asiyat AbdulKareem (through her father), Moriam Oyeniyi and the Muslim Students Society of Nigeria. ${ }^{55}$

The friction rancor and fury, due to religious differences, rage and occasionally bubble to the surface. For instance, at the University of Ibadan, there have been lingering crises over the display of the cross in the school. ${ }^{56}$ Contention over the wearing of hijab in state schools is indeed a long-running and lingering issue with which states have continued to grapple with limited success. We have witnessed similar crises in Kwara and Oyo State schools and institutions. ${ }^{57}$ The issue here is not that states banned the wearing of hijab by female Muslim pupils, but that students are not allowed to wear it as part of their school uniform in state schools.

52 See the judgment in Sheik Salaudeen Ade Olayiwola $\mathcal{E} 3$ Others $v$ The Government of Osun State.

53 Olarinoye G. 2016. "Hijab crisis: How Osun schools turned religious war theatres", Vanguard, 15 June.

54 The South Western Region of Nigeria comprises Osun Oyo, Lagos, Ondo, Ekiti and Ogun States. These states have a mix of Christians and Muslims.

55 See Godwin AC. 2017. "Appeal Court upholds use of Hijab in Lagos public schools", Daily Post, 8 February.

56 Hackett RIJ. 1999. “Conflict in the Classroom: Educational Institutions as Sites of Religious Tolerance Intolerance in Nigeria", Brigham Young University Law Review 537.

57 Sheen M, Yekani HAK and Jordan TR. 2018. "Investigating the effect of wearing the hijab: Perception of facial attractiveness by Emirati Muslim women living in their native Muslim country", PLoS ONE 13(10):e0199537. 
Unfortunately, this school policy has not gone down well with some segments of the Muslim population, who see it as an abuse of the religious rights of students.

To take a critical look at these issues over the hijab, we must ask: Will it not be discriminatory if Muslim pupils wear hijab and other religious students are not allowed wear religious clothing? Does this tackle purported discrimination against a group while sanctioning discrimination against others? As far as the school uniform, it is arguable that there should be religious neutrality that is unbiased for or against any religion. As a state school, should not the school uniform be religiously neutral, or at least in principle unbiased for and against any religion? Are the Islamic enthusiasts who are actually saying that wearing the school uniform without the hijab discriminates against them correct? Are these state school uniforms "Christian clothes"?

In Osun State, if the government will not allow children from Christian, Aladura ${ }^{58}$ and if $a^{59}$ worshipping families to wear religious clothing and symbols as part of the school uniforms, why should Muslim girls be allowed to use their religious clothes as part of their school uniform? It is also important to note that there seems not to be an actual educational value of the uniform to the scientific and critical thinking of the students. It is clear that the quality of learning and value addition has nothing whatsoever to do with hijab or school uniforms. It is important for all stakeholders to see the need for our children to learn in a conducive environment devoid of the hatred and rancor which may be caused by uniform controversies. The emergence of sects within both Islam and Christianity in Nigeria, with leaders who are deemed to preach hatred and intolerance, is creating a widening gulf between the followers of the two major religions. This is contrary to the resolve of the people as reflected in the preamble to the Nigerian Constitution, with its admonition to the Nigerian people "to live in unity and harmony as one indivisible and indissoluble sovereign nation". ${ }^{6}$

\section{CONCLUSION}

Religious pluralism in Nigeria is a reality, and for it to have a beneficial rather than a detrimental effect on the country, as it has at the moment, the following recommendations must be made. First, the government should establish an interreligious regulatory body charged with the responsibility of educating religious leaders on the core values of religious tolerance and the need for peaceful coexistence amongst diverse religions. In the words of the Sultan of Sokoto, "A nation can indeed

58 Aladura Christianity, practised amongst the Yoruba of Nigeria, is a distinctive form of African Christianity that requires members to wear white robe (the soutane) as a garment of worship.

59 Ifa is a West African religion and system of divination. The worshippers are dressed in white apparel.

60 See Constitution of the Federal Republic of Nigeria, preamble. 
survive civil war and ethnic war, but no nation can survive a religious war."61 The proposed interreligious regulatory body should comprise leaders of the various religious groups. They should be persons of impeccable character who have a track record of commitment to the unity of Nigeria.

Second, there is also the need for religious preachers to emphasise the nexus between physical acts of worship and moral values of peace, honesty, brotherhood, and love. God's love, fear of God and respect for the dignity of the human person should be the focal point of preacher's messages to their followers. While the dispute resolution traditions of Christianity and Islam may differ in the scope of issues they hear and the formality of the procedures they employ, all three certainly share one unifying theme: peacefulness is next to godliness. In a time when faith seems to be a subject brought up more to spur conflict than to resolve it, it is both ironic and reassuring to read the holiest texts of these great religions, far more extensively than can be done here, and and reflect on their common commands to get along with one another in the name of the common good.

Comparing the faith-based dispute resolution philosophies and techniques of Christianity, Islam and Judaism, and their interaction with the secular legal system, American ADR scholar R Seth Shippee and legal counsel note that,

Since time immemorial, third parties have peacefully intervened in every manner of dispute, and much of this intervention has been rooted the world's countless religious traditions. Before there were courts, there were temples; before there were judges, there were elders and priests, and before there were lawyers, there were clergymen, relatives, and neighbors. ${ }^{62}$

Although there is no law forbidding religious organisations from approaching the courts for the enforcement of their fundamental rights, litigation, however, should be the last resort when ADR has fails. In a multireligious nation, such as Nigeria, litigation seems not to be the best option for the resolution of religious disputes. However, with ADR parties can seek conciliation and peaceful settlement of issues through a win-win ADR platform. When it comes to religion and human conflict, blessed are the negotiators, the mediators and the arbitrators, for they shall be called the children of God and Allah. ${ }^{63}$

61 Obi P. 2016. “Nigeria: No Nation Survives Religious War, Says Sultan”, This Day, 7 October.

62 Shippee R Seth. 2002. “'Blessed Are The Peacemakers': Faith-Based Approaches To Dispute Resolution", ILSA Journal of International \& Comparative Law 9(1):Article 9. Online at: https://nsuworks.nova.edu/ilsajournal/vol9/iss1/9

63 Holy Bible, Matthew 5:9. 